Discussion Paper Series No. 190

Japanese Horizontal Keiretsu and

the Performance Implications of Membership

$\begin{array}{ll}\text { Takehiko Isobe } & \begin{array}{l}\text { Kobe University } \\ \text { The Chinese University of } \\ \text { Hong Kong }\end{array} \\ \text { Shige Makino } & \begin{array}{l}\text { University of Victoria } \\ \text { Anthony Goerzen }\end{array}\end{array}$

June 2006

Discussion papers are a series of manuscripts in their draft form. They are not intended for circulation or distribution except as indicated by the author. For that reason Discussion Papers may not be quoted, reproduced or distributed without the written consent of the author. 
JAPANESE HORIZONTAL KEIRETSU AND

THE PERFORMANCE IMPLICATIONS OF MEMBERSHIP

Takehiko Isobe

Kobe University

Shige Makino

The Chinese University of Hong Kong

Anthony Goerzen

University of Victoria 


\title{
JAPANESE HORIZONTAL KEIRETSU AND THE PERFORMANCE IMPLICATIONS OF MEMBERSHIP
}

\author{
Abstract \\ Our study investigates the effect of Japanese horizontal keiretsu group membership on \\ firm risk and return. Like prior studies, our results show that horizontal keiretsu membership has \\ a negative effect on firm profitability. However, we find that horizontal keiretsu networks are \\ likely to increase the gap between targeted and realized returns, which we call the outcome- \\ aspiration gap. Moreover, in contrast to prior studies, our results indicate that keiretsu \\ membership does not enable member firms to reduce risks by smoothing profitability. Instead, \\ our findings provide evidence that is counter to the conventional notion that Japanese horizontal \\ keiretsu allow their member firms to trade off profits for reduced risk. \\ keywords: horizontal keiretsu \\ performance \\ risk sharing
}




\section{INTRODUCTION}

A prevailing view of the motivations that underlie the incentives to become and/or remain a member of a Japanese horizontal keiretsu is that keiretsus play a role as an insurance mechanism for firms by protecting them from foreign takeovers, providing financial support in troubled times, and creating preferential purchasing arrangements (Dow \& McGuire, 1999; Gerlach, 1992). Tabeta (1998) and Tabeta and Rahman (1999), for example, suggested that keiretsu members may mitigate opportunism within small numbers bargaining. Further, Wang, Huang, and Bansal (2005) found that keiretsu firms derive a benefit from membership in an economic crisis. In return for this insurance against risk, horizontal keiretsu members accept lower average profitability (Lincoln, Gerlach, \& Ahmadjian, 1996; Nakatani, 1984; Weinstein \& Yafeh, 1995). Thus, horizontal keiretsu members are generally considered to prefer low risks and low returns, where profit is sacrificed in exchange for a reduction in firm performance variability.

Japan's horizontal keiretsu system, however, is currently in a state of significant change. As reported by Business Week, for example, these networks appear to be under great pressure to disaggregate and restructure due to recent shifts in the global business environment that have diminished the ability of the horizontal keiretsu system to deliver the intended benefits (see, e.g., Business Week; March 15, 1999). At the corporate level, member firms such as Niigata Steel have gone bankrupt, Mitsui Mining and Japan Metals \& Chemicals are reconstructing their organizations, and Toho Rayon has been integrated by another keiretsu group firm. Another example of this trend is the merger of Sakura Bank (from the Mitsui keiretsu) with Sumitomo Bank to create Mitsui-Sumitomo Bank. Also, Mizuho Financial Group has joined with Fuji Bank (from the Fuyo keiretsu), Dai-Ichi Kangyo Bank (from the DKB keiretsu), and the independent Industrial Bank of Japan. Restructuring among keiretsu networks has also been observed in the 
insurance, steel, and chemical industries. These changes are significant because the six major keiretsu groups exert a great deal of influence on the Japanese economy (Dow \& McGuire, 1999); excluding banks, they hold 13.2 percent of total capital of the Japanese listed companies in 1999. In terms of total assets and sales of Japanese listed companies, they hold 11.2 and 10.8 percent respectively (Japan Fair Trade Commission, 2001).

If keiretsu members truly enjoy a beneficial risk/return tradeoff, as suggested by previous studies, it is unclear why horizontal keiretsu are restructuring and/or reorganizing. The objective of this paper, therefore, is to re-examine the conventional thinking on the relationship between keiretsu membership and the risk and return performance of keiretsu members, since recent significant changes both outside and inside group firms have cast doubt on the traditional view that group membership leads to a net economic benefit. Although the research on business groups has become an important topic in the field of strategic management as well as network theory (Tabeta, 1998; Tabeta \& Rahman, 1999; Wang et al., 2005), we still know very little about how business group membership influences the performance outcomes of member firms (Gulati, 1998; Khanna \& Rivkin, 2001).

Although some previous studies used the keiretsu definition suggested by the Research on Keiretsu (RoK), Miwa and Ramseyer (2002: 171) suggested that "the RoK merely allocates firms by the principal source of their loans - not cross-shareholdings, not trading ties, not personnel exchanges" and thus RoK measure is unsuitable for classification of horizontal keiretsu. Therefore, in this study, we define the horizontal keiretsu as the six major bank-centred groups and a reliable indicator of membership within these groups as defined by inclusion in the keiretsu Presidents' Council. 


\section{THE JAPANESE HORIZONTAL KEIRETSU SYSTEM}

The horizontal keiretsu is a dual faceted organizational system. It is a governance system that structures economic transactions among diversified member firms through the use of incentive mechanisms (e.g., Dalton, Daily, Ellstrand, \& Johnson, 1998). Horizontal keiretsu also represent social systems in which economic transactions are embedded in social network of the member firms (Granovetter, 1994, 1995). Keiretsu membership therefore affects performance (both risk and return) of member firms by influencing the structure and the nature of their economic transactions through its unique governance mechanism and social exchanges among member firms.

\section{Positive Effects of Keiretsu Membership on Performance}

Research suggests that horizontal keiretsu membership reduces risks in several ways. First, horizontal keiretsu member firms mutually monitor the activities of other members, exchange personnel, share information as well as capital, and maintain cross-shareholdings. Mutual monitoring and information sharing reduce information asymmetry among the member firms, thereby reducing transaction costs. Reduced information-asymmetry and crossshareholding together also reduce the agency problem between managers and owners of member firms. Further, internal capital sharing reduces financial costs. Cross-shareholdings among the member firms reduce the risks of hostile takeovers. In particular, the main bank system in a horizontal keiretsu is said to play a central role in reducing agency problems between owners, debtors, and managers of the horizontal keiretsu member firms. Main banks are the largest debtors, and often the major shareholders, of the member firms and have information advantages over other financial institutions due to their long-term relationships. As a result, the main banks suffer fewer agency problems and, therefore, horizontal keiretsu membership relieves liquidity 
constraints (Aoki, 1990; Hoshi, Kashyap, \& Scharfstein, 1991).

The bank-centered horizontal keiretsu system provides a so called "insurance mechanism" (Nakatani, 1984). When a member firm is financially distressed, for example, the main bank in a horizontal keiretsu group normally takes the initiative in lending capital to or investing in the troubled firm, sometimes dispatching personnel to the corporate board of the troubled firm (Sheard, 1989). Hoshi, Kashyap, and Scharfstein (1990) and Lincoln, et al. (1996), for example, found that the bank-centered horizontal keiretsu structure reduced the financial risk of the member firms when they encountered significant economic distress and that those member firms with stronger main bank affiliations were less likely to fail.

Horizontal keiretsu member firms also mitigate financial risks by sharing know-how with member firms operating in different industries. Prior research has suggested that member firms often transfer technological solutions from one industry to solve issues in another where those solutions were either rare or unknown (e.g., Hargadon \& Sutton, 1997; Sutton \& Hargadon, 1996). In fact, a survey conducted by the Japan Fair Trade Commission (2001) also indicated that know-how, information, and brand sharing are among the most critical means of risk reduction in a horizontal keiretsu group.

Horizontal keiretsu membership may also enhance the profitability of member firms in several ways. First, horizontal keiretsu firms have greater reputation and recognition than do independent firms. The member firms benefit from the group's overall reputation in that they can more easily attract talented employees, build strong market recognition and presence, and negotiate better deals with financial, government, and professional institutions, as well as with market intermediaries such as suppliers and customers. Second, horizontal keiretsu members share strong social ties, which shape economic actions by creating unique opportunities and 
access to those opportunities (Uzzi, 1996). Firms with strong ties develop social capital among member firms through which they exchange and combine tacit and complementary knowledge to create unique intellectual capital, which in turn contributes to development of organizational advantages (Burt, 1992; Nahapiet \& Ghoshal, 1998). Member firms also benefit from investment in relation-specific assets that facilitates joint learning and production, and reduces opportunism in transactions by enforcing formal safeguards (e.g., financial and investment hostages) as well as informal safeguards (e.g., goodwill, trust, and embeddedness), all of which contribute to enhancing relational rents of the member firms (Dyer \& Singh, 1998).

\section{Negative Effects of Keiretsu Membership on Performance}

Horizontal keiretsu membership may also have a negative impact on firm performance. One source of this negative impact lies in the fact that horizontal keiretsu member firms tend to favour strongly economic transactions with firms within their own horizontal keiretsu. Thus, member firms would have limited opportunities to explore external partners who may offer better transactional opportunities because they may possess superior complementary assets as compared to member firms and/or may be more willing to share financial risks through joint operations and learning. The confinement of transactions within the horizontal keiretsu boundaries, therefore, lowers the profitability of member firms due to limited access to external profit opportunities and increases in agency costs due to limited diversification opportunities.

A second source of the negative effect of horizontal keiretsu membership is that the horizontal keiretsu requires a great deal of coordination. Member firms are active in a variety of unrelated businesses that have diverse demands, facing diverse challenges. Thus, coordination of the various, perhaps even competing, interests is a source of significant costs. Gulati and Singh (1998: 782), for example, argue that coordination costs stem from "the anticipated organizational 
complexity of decomposing tasks among partners along with ongoing coordination of activities to be completed jointly or individually across organizational boundaries and the related extent of communication and decisions that would be necessary." Difficulties in coordination inflate transaction costs and thus reduce profits of member firms. These difficulties also destabilize transactions among the member firms and hence increase the risk of unsatisfactory outcomes.

Third, the horizontal keiretsu member firm may be subject to greater risk for reasons that relate to the inner workings of these groups' financial structures. For example, horizontal keiretsu member firms appear to be more highly leveraged and are less liquidity constrained than non-horizontal keiretsu firms due to their greater reliance on loans from their central banks (Hoshi et al., 1990). Consequently, horizontal keiretsu members are faced with greater financial risk than non-horizontal keiretsu firms because the former have a greater reliance on a single sources of financing than do the latter (Hoshi et al., 1991).

Finally, social relationships developed within a horizontal keiretsu may not be easily transferred to outside the boundary of the horizontal keiretsu group. While social relationships make exchanges of know-how and information among the member firms more efficient, they can also become a source of inertia which may impede an ongoing need for adaptation and adjustment. Coleman (1990), for example, noted that a "given form of social capital that is useful for facilitating certain actions may be useless or harmful for others.” Thus, the existing strong social relationships may make partnerships between the member firms less flexible to changes and often promote a competency trap (Levitt \& March, 1988) in which the firms make escalating commitments to investment in existing competences. Rigidity in social relationships increases the risks of organizational change and keeps the member firms from exploring new business transactions with other partners, which impede profit opportunities that these member firms 
could have.

In general, prior research does not provide clear evidence that diversified businesses organized within a corporate group, as is typically observed in a horizontal keiretsu, perform better or even as good as business groups that are more closely related (see e.g., Christensen \& Montgomery, 1981; Lubatkin \& Chatterjee, 1994; Ramanujam \& Varadarajan, 1989), suggesting that the positive relationship between horizontal keiretsu membership and return remains an empirical question. Furthermore, a growing number of studies provide evidence that there are many cases in which risk sharing mechanisms either do not exist or do not function well in certain business groups (Khanna \& Yafeh, 2005). Taken together, this suggests that horizontal keiretsu membership may not provide a beneficial risk and return trade off as has been suggested in some prior research. Therefore, we examine this question to shed new light on this important question.

\section{METHODOLOGY}

Data. In this paper, we use the sample from Nakatani's (1984) study, which listed 317 firms since one of our research objectives is to compare our findings with prior research. We use 269 firms, which can be observed for 24 years between $1977-2000^{1}$. Of the 269 firms that appeared over this period, 57 are firms that belong to the Presidents' Council (i.e., Shacho-kai) of the six major horizontal keiretsu groups, while 212 are independent firms. The annual data for each sample firm are collected from the Nikkei NEEDS, one of the most reliable and comprehensive sources of financial and non-financial information on the listed firms in Japan.

Dependent variables. Both net profits on assets (RoA) and sales (RoS) are used as

\footnotetext{
${ }^{1}$ Of 48 firms which disappeared from Nakatani's list, 23 firms have gone bankrupt or delisted from stock markets and 25 firms were merged or integrated. As a robustness check, we used all firms listed in Tokyo Stock Market as of the year of 2000, the results are quite similar to those of this study suggesting that the elimination of the firms from Nakatani's sample does not bias our results.
} 
measures of firm profitability. We calculate the mean of difference $\left(r_{i, t}\right)$ between firm's profitability and industry average profitability for observation period $(n)$ as

$$
\text { Firm profitability }=\frac{1}{n} \sum r_{i, t}=\frac{1}{n} \sum\left(R_{i, t}-R_{j, t}\right)
$$

where $R_{i, t}$ is RoA or RoS of firm $i$ at time $t$ and $R_{j, t}$ is the average RoA or RoS of industry $j$ at time $t$. In this study, we classify industries into 19 categories based on the definition of Nikkei NEEDS.

Prior research has investigated the relationship keiretsu membership and firm risk. Nakatani (1984) and Khanna and Yafeh (2005), for example, found a negative relationship between variance of operating income on assets and keiretsu membership. However, in these studies, risk is often defined as the extent to which there is uncertainty about whether expected outcomes will be realized (Sitkin \& Pablo, 1992). Underlying this definition is that risk can be measured as the gap between realized and targeted outcomes, which we call here the "outcomeaspiration gap." To calculate the outcome-aspiration gap, we obtain data from Kessan Tanshin (flash reports of financial results), which is an overview of financials and listed firms in Japanese stock markets which have an obligation to disclose financial information prior to settling accounts at the general meeting of shareholders. One of unique feature of Kessan Tanshin is that this report contains information on financial aspiration level for next year. We calculate the outcome-aspiration gap by subtracting targeted RoS from realized RoS on an annual basis and then averaging these values over observation period as

$$
\text { Outcome-aspiration gap }=\frac{1}{n} \sum\left|r_{i, t}-l_{i, t}\right|,
$$

where $l_{i, t}$ is the difference of targeted RoS of firm $i$ and that of industry average. Targeted RoS is usually determined at the time of $t-1$. Although strategic management researchers often use the 
term risk to mean downside unpredictability of business outcome variables (e.g., Miller \& Reuer, 1996), we include a full range of outcomes, either positive and negative (Sitkin \& Pablo, 1992). In addition to the outcome-aspiration gap, we add standard deviation measures of RoS and RoA into our analysis to enable us to compare our results with prior studies.

Independent variables. In this paper, we focus on the six major industrial groups in Japan, the horizontal or bank-centered horizontal keiretsu: Mitsui, Mitsubishi, Sumitomo, Fuyo, DKB, and Sanwa (Flath, 1996; Khanna \& Yafeh, 2005). Prior studies commonly identified keiretsu membership as the Research on Keiretsu (RoK), Dodwell's Industrial Groups in Japan, or Toyo Keizai's Kigyo Keiretsu Soran. In this study, we rely on the definition of the Kigyo Keiretsu Soran, because our interests are in the specific details of keiretsu membership. The relationships among member firms are characterized by cross-shareholding, central bank financing, information exchange, long term contracting, and exchange of executive officers among the member firms within their groups. Based on Lincoln et al. (1996), we use three variables to define horizontal keiretsu; membership in the Presidents' Council, equity ties, and debt ties. Membership in the Presidents' Council is measured by a dummy variable, coded as one for those firms that belong to a horizontal keiretsu group and zero for independent firms. Measures of equity ties and debt ties are used because they reflect the strength of the firms' keiretsu dependence. In addition, we add the keiretsu definition of RoK to enable us to compare our research with prior studies.

We also include several firm-specific variables. For example, firm size and age are included since horizontal keiretsu firms are larger and older than non-horizontal keiretsu firms, on average. In addition, we control for product and geographical diversification as they factors may have significant effects on annual changes of profitability. We use the entropy concept as a 
measurement of product diversification (Palepu, 1985), since this measure is superior to other metrics (Attaran \& Zwick, 1987). The diversification data were obtained the Japan Company Handbook based on Delios and Beamish (1999). We employed the export ratio as geographical expansion, which is hypothesized to influence firm risk negatively. In addition, we include a measure of slack resources in our models since scholars have found that a firm's slack has a significant effect on firm risk and return given that these resources facilitate information gathering and environmental adaptation (Bourgeois \& Singh, 1983; Bromiley, 1991; Greve, 2004). Following prior studies, we use the current ratio (ratio of current asset to liabilities) and debt ratio (the ratio of debt to equity) to measure the degree of slack resources. All control variables are averaged. Table 1 provides the descriptive characteristics and correlation coefficients among our variables for observation period.

insert Table 1 about here

In this paper, we examine the associations between firm risk/return and keiretsu membership using maximum likelihood estimation for multiple regression. All tests for statistical significance are two-tailed.

\section{RESULTS}

Like previous studies (e.g., Khanna \& Yafeh, 2005; Nakatani, 1984), Table 2 shows that horizontal keiretsu membership is negatively and statistically significantly associated with both firm profitability (i.e., RoA and RoS adjusted by industry average) over the periods of 19772000. For example, the regression coefficients of the Presidents' Council membership dummy is significantly associated with $\operatorname{RoA}(\beta=-0.37, \mathrm{p}<0.1)$ and with $\operatorname{RoS}(\beta=-0.40, \mathrm{p}<0.1)$. The coefficients of debt ties within keiretsu are also negatively and significantly associated with RoA 
$(\beta=-0.01, p<0.1)$, although we did not find a statistically significant relationship between debt ties and RoS.

insert Table 2 about here

In contrast to prior studies such as Nakatani (1984), Table 3 shows that the regression coefficients of keiretsu measures are positively and significantly associated with outcomeaspiration gap: Presidents' Council measure $(\beta=0.39 \mathrm{p}<0.01)$, equity ties $(\beta=0.01, \mathrm{p}<0.1)$, and debt ties $(\beta=0.01 \mathrm{p}<0.05)$. However, according to the RoK definition, keiretsu membership is not significantly associated with the outcome-aspiration gap.

insert Table 3 about here

Table 4 shows the keiretsu membership (i.e., Presidents' Council) dummy is positively and significantly associated with both volatility of $\operatorname{RoA}(\beta=0.25, \mathrm{p}<0.1)$ and $\operatorname{RoS}(\beta=0.32, \mathrm{p}$ $<0.01)$. Debt ties are also positively and significantly associated with volatility of $\operatorname{RoA}(\beta=0.01$, $\mathrm{p}<0.1)$ and $\operatorname{RoS}(\beta=0.01, \mathrm{p}<0.01)$, although equity ties have positive but insignificant effects on volatility of both measures of profitability. These results suggest that keiretsu membership is associated with the volatility of firm RoS rather than RoA. It is surprising that, like Table 3, the RoK definition keiretsu dummy is negative but insignificantly associated with volatility.

insert Table 4 about here

As for control variables, firm size has a positive effect on firm profitability and negative effect on volatility. The current ratio has a positive effect on firm profitability, although the debtequity ratio is negatively associated. Geographic expansion and export ratio have statistically 
significant and positive effects on firm risk. We cannot find any effect of diversification on risk and return.

\section{CONCLUSION}

This study examines the relationship between horizontal keiretsu membership and firm performance. In addition to defining firm risk as the standard deviation of profitability, we measure deviation between targeted and realized outcomes over the observation period. Although prior studies have often defined firm risk simply as the standard deviation of outcomes (Nakatani, 1984, Khanna \& Yafef, 2005), our measures more fully account for risk within keiretsu. Our results, using both standard deviation and the outcome-aspiration gap, do not support the conventional belief that horizontal keiretsu member firms are more likely to achieve lower risks and have more stable profits than independent firms. This implies that the reason for a firm to continue to be a member of horizontal keiretsu network might not be driven by an economic rationale.

One plausible explanation for the persistence of keiretsu is that the long-term relationships among keiretsu members that include cross-share holding, financial interdependency with the main banks, and close trading with member firms may build intangible exit barriers, or be a cause of inertia, from exiting the keiretsu system. Therefore, even if member firms acknowledge that membership does not provide a net economic incentive, they may be very slow to leave nonetheless.

Thus, the continued (although declining) existence of horizontal keiretsu groups may be explained by social returns including legitimacy building and reputation spillovers. Perhaps horizontal keiretsu networks could better be viewed as communities in which social integration gives rise to security and mutual assurance among decision makers through coordination and 
information sharing rather than as a governance structure that enables efficient integration of economic transactions among the member firms.

The results of our analysis suggest some avenues for future research. First, Table 4 shows that our keiretsu measures have positive and significant effects on firm risk, but RoK has no significant effects on both volatility of firm RoA and RoS. These results suggest that the effects of horizontal keiretsu membership on firm risk may vary according to the measures of keiretsu membership ${ }^{2}$. We do not imply that previous studies are incorrect or misguided, but simply that there is doubt that group membership necessarily provides a beneficial economic trade off for keiretsu member firms. Thus, further study on the relationship between keiretsus and firm performance needs to retain a focus on accurate definitions and sharp measures of keiretsu membership.

Second, our study indicates that some firm specific variables are highly associated with firm performance. For example, firm size has a positive and significant impact on profitability and has a negative and statistically significant impact on firm risk. Firm age is not significantly associated with both profitability and significant impact on firm risk. Although the results of our analysis did not support the argument that internal risk sharing mechanisms, such as product and geographical diversification, play a significant role in reducing the risks, a future research effort might extend this line of thought by identifying the conditions and factors affecting firms' choices between external risk sharing mechanisms (e.g., business groups and horizontal keiretsu) and internal risk sharing mechanisms (e.g., diversification).

Finally, there has been recently an increasing number of researchers that are focusing on

\footnotetext{
${ }^{2}$ Prior studies have controlled for industry effects on firm risk by using dummy variables. Our results show that keiretsu membership is negatively associated with volatility of firm profitability which is consistent with prior studies. Thus, the relationship between keiretsu membership and firms risk is clearly influenced by the methodological techniques to control the industry effects.
} 
various types of business groups in Asia (Carney, 2005; Carney \& Gedajlovic, 2003; Chu, 2001; Khanna \& Palepu, 1997; Kim, Hoskisson, \& Tihanyi, 2004; Peng, 2003). Some of these researchers argued that the advantages of business groups are contingent upon the stage of institutional economic development. In emerging economies, for example, where institutional voids impede efficient market transactions, business groups may be more efficient forms of governance than market mechanisms (Khanna \& Palepu, 1997; Peng, 2003). Our results suggest, however, that recent significant changes to the keiretsu organization may be caused by the fact that the costs of the keiretsu system appears to outweigh the benefits and that, in economically developed institutional environments, keiretsu membership is becoming increasingly difficult to justify. 


\section{REFERENCES}

Aoki, M. 1990. Toward an economic model of the Japanese firm. Journal of Economic Literature, 28(1): 1-27.

Attaran, M., \& Zwick, M. 1987. Entropy and other measures of industrial diversification. Quarterly Journal of Business and Economics, 26(4): 17-34.

Bourgeois, L., \& Singh, J. 1983. Organizational slack and political behavior among top management teams. Academy of Management Proceedings: 43-47.

Bromiley, P. 1991. Testing a causal model of corporate risk taking and performance. Academy of Management Journal, 34(1): 37-59.

Burt, R. 1992. Structural holes: The social structure of competition. Harvard University Press: Cambridge.

Carney, M. 2005. Globalization and the renewal of Asian business networks. Asia Pacific Journal of Management, 22(4): 337-354.

Carney, M., \& Gedajlovic, E. 2003. Strategic innovation and the administrative heritage of East Asian family business groups. Asia Pacific Journal of Management, 20(1): 5-26.

Christensen, H., \& Montgomery, C. 1981. Corporate economic performance: Diversification strategy versus market structure. Strategic Management Journal, 2(4): 327-344.

Chu, W. 2001. Contingency organizations and shared values: Multiple logics in managing diversification. Asia Pacific Journal of Management, 18(1): 83-99.

Coleman, J. 1990. Foundations of social theory. Belknap Press: Cambridge, MA.

Dalton, D., Daily, C., Ellstrand, A., \& Johnson, J. 1998. Meta-Analytic reviews of board composition, leadership structure, and financial performance. Strategic Management Journal, 19(3): 269-290.

Delios, A., \& Beamish, P. 1999. Geographic scope, product diversification, and the corporate performance of Japanese firms. Strategic Management Journal, 20(8): 711-727.

Dow, S., \& McGuire, J. 1999. The sources and advantages of Japanese industrial organization. Asia Pacific Journal of Management, 16(1): 47-74.

Dyer. J., \& Singh, H. 1998. The relational view: Cooperative strategy and sources of interorganizational competitive advantage. Academy of Management Review, 23(4): 660-679.

Flath, D. 1996. The keiretsu puzzle. Journal of the Japanese and International Economies, 10(2): 101-121.

Gerlach, M. 1992. Alliance capitalism: The social organization of Japanese business. 
University of California Press: Los Angeles.

Granovetter, M. 1994. Business groups. In N. Smelser, \& R. Swedberg. (Eds.), The Handbook of Economic Sociology: 453-475. Princeton University Press: Princeton.

Granovetter, M. 1995. Coase revisited: Business groups in the modern economy. Industrial and Corporate Change, 4(1): 93-130.

Greve, H. 2004. A behavioral theory of R\&D expenditures and innovations: Evidence from shipbuilding. Academy of Management Journal, 46(6): 685-702.

Gulati, R. 1998. Alliances and networks. Strategic Management Journal, 19(4): 293-317.

Gulati, R., \& Singh, H. 1998. The architecture of cooperation: Managing coordination costs and appropriation concerns in strategic alliances. Administrative Science Quarterly, 43(4): 781-815.

Hargadon, A., \& Sutton, R. 1997. Technology brokering and innovation in a product development firm. Administrative Science Quarterly, 42(4): 716-749.

Hoshi, T., Kashyap, A., \& Scharfstein, D. 1990. The role of banks in reducing the costs of financial distress in Japan. Journal of Financial Economic, 27(1): 67-88.

Hoshi, T., Kashyap, A., \& Scharfstein, D. 1991. Corporate structure, liquidity, and investment: Evidence from Japanese industrial groups. Quarterly Journal of Economics, 106(1): 33-60.

Japan Fair Trade Commission. 2001. State of corporate groups in Japan: the seventh survey report. 12-01-001.264-00-A. The Fair Trade Commission: Washington, CD.

Khanna, T., \& Palepu, K. 1997. Why focused strategies may be wrong for emerging markets. Harvard Business Review, 75(4): 41-49.

Khanna, T., \& Rivkin, J. 2001. Estimating the performance effects of business groups in emerging markets. Strategic Management Journal, 22(1): 45-74.

Khanna, T., \& Yafeh, Y. 2005. Business groups and risk sharing around the world. Journal of Business, 78(1): 301-340.

Kim, H., Hoskisson, R., \& Tihanyi, L. 2004. The evolution and restructuring of diversified business groups in emerging markets: The lessons from chaebols in Korea. Asia Pacific Journal of Management, 21(1-2): 25-48.

Levitt, B., \& March, J. 1988. Organizational learning. Annual Review of Sociology, 14: 319-340.

Lincoln, J., Gerlach, M., \& Ahmadjian, C. 1996. Keiretsu networks and corporate performance in Japan. American Sociological Review, 61(1): 67-88.

Lubatkin, M., \& Chatterjee, S. 1994. Extending modern portfolio theory into the domain of corporate diversification: Does it apply? Academy of Management Journal, 37(1): 109-136. 
Miller, K., \& Reuer, J. 1996. Measuring organizational downside risk. Strategic Management Journal, 17(9): 671-691.

Miwa, Y., \& Ramseyer, J. 2002. The fable of the keiretsu. Journal of Economics and Management Strategy, 11(2): 169-224.

Nahapiet, J., \& Ghoshal, S. 1998. Social capital, intellectual capital, and the organizational advantage. Academy of Management Review, 23(2): 242-266.

Nakatani, I. 1984. The economic role of financial corporate grouping. In M. Aoki (Ed.), The economic analysis of the Japanese firm: 227-258. North-Holland: Amsterdam.

Palepu, K. 1985. Diversification strategy, profit performance, and the entropy measure of diversification. Strategic Management Journal, 6(3): 239-255.

Peng, M. 2003. Institutional transitions and strategic choices. Academy of Management Review, 28(2): 275-286.

Ramanujam, V., \& Varadarajan, P. 1989. Research on corporate diversification: A synthesis. Strategic Management Journal, 10(6): 523-551.

Sheard, P. 1989. The main bank system and corporate monitoring and control in Japan. Journal of Economic Behavior and Organization, 11(3): 399-422.

Sitkin, S., \& Pablo, A. 1992. Reconceptualizing the determinants of risk behavior. Academy of Management Review, 17(1): 9-39.

Sutton, R., \& Hargadon, A. 1996. Brainstorming groups in context: Effectiveness in a product design firm. Administrative Science Quarterly, 41(4): 685-718.

Tabeta, N. 1998. The kigyo keiretsu organization and opportunism in the Japanese automobile manufacturing industry. Asia Pacific Journal of Management, 15(1): 1-18.

Tabeta, N., \& Rahman, S. 1999. Risk sharing mechanism in Japan's auto industry: The keiretsu versus independent parts suppliers. Asia Pacific Journal of Management, 16(3): 311-330.

Uzzi, B. 1996. The sources and consequences of embeddedness for the economic performance of organizations: The network effect. American Sociological Review, 61(4): 674-699.

Wang, H., Huang, P., \& Bansal, P. 2005. What determined success during the Asian economic crisis?: The importance of experiential knowledge and group affiliation. Asia Pacific Journal of Management, 22(1): 89-106.

Weinstein, D., \& Yafeh, Y. 1995. Japan's corporate groups: Collusion or competitive? An empirical investigation of keiretsu behavior. Journal of Industrial Economics, 43(4): 359-376. 
Table 1. Descriptive statistics and correlations

\begin{tabular}{|c|c|c|c|c|c|c|c|c|c|c|c|c|c|c|c|c|c|}
\hline & Variable & Mean & s.d. & 1 & 2 & 3 & 4 & 5 & 6 & 7 & 8 & 9 & 10 & 11 & 12 & 13 & 14 \\
\hline 1 & $\begin{array}{l}\text { Presidents' Council } \\
\text { membership }\end{array}$ & 0.21 & 0.41 & & & & & & & & & & & & & & \\
\hline 2 & Equity ties & 5.01 & 11.83 & $0.82 *$ & & & & & & & & & & & & & \\
\hline 3 & Debt ties & 5.64 & 12.04 & $0.90 *$ & $0.82 *$ & & & & & & & & & & & & \\
\hline 4 & RoK definition & 0.71 & 0.45 & $0.21 *$ & 0.10 & $0.21 *$ & & & & & & & & & & & \\
\hline 5 & RoA & -0.15 & 1.32 & -0.07 & -0.08 & -0.10 & -0.02 & & & & & & & & & & \\
\hline 6 & $\operatorname{RoS}$ & -0.12 & 1.66 & -0.08 & -0.08 & -0.08 & -0.06 & $0.90^{*}$ & & & & & & & & & \\
\hline 7 & RoA Volatility & 1.40 & 1.24 & -0.09 & -0.06 & -0.06 & -0.06 & $-0.34 *$ & $-0.38^{*}$ & & & & & & & & \\
\hline 8 & RoS Volatility & 1.63 & 1.98 & -0.04 & -0.02 & 0.00 & -0.10 & $-0.26^{*}$ & $-0.28 *$ & $0.88^{*}$ & & & & & & & \\
\hline 9 & $\begin{array}{l}\text { Outcome-aspiration } \\
\text { gap }\end{array}$ & 2.09 & 1.98 & -0.03 & -0.02 & -0.02 & -0.12 & $-0.21 *$ & $-0.26^{*}$ & $0.69 *$ & $0.86 *$ & & & & & & \\
\hline 10 & Size & 5.04 & 0.51 & $0.39 *$ & $0.22 *$ & $0.30 *$ & 0.16 & $0.20 *$ & 0.12 & $-0.39^{*}$ & $-0.40^{*}$ & $-0.33^{*}$ & & & & & \\
\hline 11 & Age & 63.37 & 19.99 & $0.20 *$ & 0.06 & 0.17 & 0.10 & 0.02 & 0.07 & -0.07 & -0.01 & 0.04 & 0.05 & & & & \\
\hline 12 & Diversification & 1.09 & 0.34 & 0.05 & 0.02 & 0.02 & 0.11 & 0.00 & 0.02 & -0.11 & -0.06 & -0.05 & 0.10 & -0.01 & & & \\
\hline 13 & Exports & 15.55 & 15.66 & 0.06 & 0.03 & 0.03 & -0.09 & 0.05 & 0.02 & 0.14 & 0.11 & 0.07 & $0.30 *$ & $-0.19^{*}$ & -0.02 & & \\
\hline 14 & Current ratio & 116.37 & 75.64 & -0.15 & -0.11 & -0.16 & -0.15 & $0.52 *$ & $0.65^{*}$ & $-0.18^{*}$ & -0.09 & -0.05 & -0.15 & -0.01 & 0.02 & 0.01 & \\
\hline 15 & Debt equity ratio & 356.97 & 534.38 & 0.07 & 0.11 & 0.11 & 0.03 & $-0.36^{*}$ & $-0.32 *$ & $0.18^{*}$ & 0.16 & 0.05 & -0.10 & 0.02 & -0.10 & -0.07 & $-0.30^{*}$ \\
\hline
\end{tabular}


Table 2. Regression results for profitability

\begin{tabular}{|c|c|c|c|c|c|c|c|c|c|c|c|c|c|c|c|c|}
\hline \multirow[b]{3}{*}{$\begin{array}{l}\text { Presidents' Council } \\
\text { membership }\end{array}$} & \multicolumn{8}{|c|}{ Return on assets (RoA) } & \multicolumn{8}{|c|}{ Return on sales (RoS) } \\
\hline & \multicolumn{2}{|c|}{ Model 1} & \multicolumn{2}{|c|}{ Model 2} & \multicolumn{2}{|c|}{ Model 3} & \multicolumn{2}{|c|}{ Model 4} & \multicolumn{2}{|c|}{ Model 5} & \multicolumn{2}{|c|}{ Model 6} & \multicolumn{2}{|c|}{ Model 7} & \multicolumn{2}{|c|}{ Model 8} \\
\hline & $\begin{array}{l}-0.3697 \\
(0.1771)\end{array}$ & + & & & & & & & $\begin{array}{r}-0.3970 \\
(0.2005)\end{array}$ & + & & & & & & \\
\hline Equity ties & & & $\begin{array}{r}-0.0075 \\
(0.0057)\end{array}$ & & & & & & & & $\begin{array}{l}-0.0091 \\
(0.0064)\end{array}$ & & & & & \\
\hline Debt ties & & & & & $\begin{array}{l}-0.0106 \\
(0.0048)\end{array}$ & + & & & & & & & $\begin{array}{l}-0.0084 \\
(0.0066)\end{array}$ & & & \\
\hline RoK definition & & & & & & & $\begin{array}{r}-0.0729 \\
(0.1470)\end{array}$ & & & & & & & & $\begin{array}{l}-0.0062 \\
(0.1667)\end{array}$ & \\
\hline Size & $\begin{array}{r}0.7988 \\
(0.1472)\end{array}$ & $* * *$ & $\begin{array}{r}0.9788 \\
(0.1437)\end{array}$ & $* * *$ & $\begin{array}{r}0.7610 \\
(0.1430)\end{array}$ & $* * *$ & $\begin{array}{r}0.6671 \\
(0.1379)\end{array}$ & $* * *$ & $\begin{array}{r}0.9099 \\
(0.1667)\end{array}$ & $* * *$ & $\begin{array}{r}0.8333 \\
(0.1583)\end{array}$ & $* * *$ & $\begin{array}{r}0.8454 \\
(0.1623)\end{array}$ & $* * *$ & $\begin{array}{r}0.7773 \\
(0.1568)\end{array}$ & $* * *$ \\
\hline Age & $\begin{array}{r}0.0010 \\
(0.0034)\end{array}$ & & $\begin{array}{r}-0.0002 \\
(0.0033)\end{array}$ & & $\begin{array}{r}0.0006 \\
(0.0033)\end{array}$ & & $\begin{array}{r}-0.0004 \\
(0.0033)\end{array}$ & & $\begin{array}{r}0.0051 \\
(0.0038)\end{array}$ & & $\begin{array}{r}0.0039 \\
(0.0037)\end{array}$ & & $\begin{array}{r}0.0044 \\
(0.0038)\end{array}$ & & $\begin{array}{r}0.0037 \\
(0.0038)\end{array}$ & \\
\hline Diversification & $\begin{array}{r}-0.2232 \\
(0.1915)\end{array}$ & & $\begin{array}{r}-0.2038 \\
(0.2109)\end{array}$ & & $\begin{array}{r}-0.2350 \\
(0.1919)\end{array}$ & & $\begin{array}{r}-0.2399 \\
(0.1938)\end{array}$ & & $\begin{array}{r}-0.1438 \\
(0.2168)\end{array}$ & & $\begin{array}{r}-0.1529 \\
(0.2176)\end{array}$ & & $\begin{array}{r}-0.1554 \\
(0.2178)\end{array}$ & & $\begin{array}{r}-0.1467 \\
(0.2203)\end{array}$ & \\
\hline Exports & $\begin{array}{r}-0.0051 \\
(0.0045)\end{array}$ & & $\begin{array}{r}-0.0047 \\
(0.0040)\end{array}$ & & $\begin{array}{l}-0.0052 \\
(0.0045)\end{array}$ & & $\begin{array}{l}-0.0045 \\
(0.0045)\end{array}$ & & $\begin{array}{l}-0.0069 \\
(0.0050)\end{array}$ & & $\begin{array}{l}-0.0068 \\
(0.0051)\end{array}$ & & $\begin{array}{l}-0.0069 \\
(0.0051)\end{array}$ & & $\begin{array}{r}-0.0066 \\
(0.0051)\end{array}$ & \\
\hline Current ratio & $\begin{array}{r}0.0081 \\
(0.0009)\end{array}$ & $* * *$ & $\begin{array}{r}0.0083 \\
(0.0009)\end{array}$ & $* * *$ & $\begin{array}{r}0.0082 \\
(0.0009)\end{array}$ & $* * *$ & $\begin{array}{r}0.0084 \\
(0.0009)\end{array}$ & $* * *$ & $\begin{array}{r}0.0137 \\
(0.0010)\end{array}$ & $* * *$ & $\begin{array}{r}0.0138 \\
(0.0010)\end{array}$ & $* * *$ & $\begin{array}{r}0.0137 \\
(0.0010)\end{array}$ & $* * *$ & $\begin{array}{r}0.0139 \\
(0.0010)\end{array}$ & $* * *$ \\
\hline Debt equity ratio & $\begin{array}{l}-0.0005 \\
(0.0001)\end{array}$ & $* * *$ & $\begin{array}{l}-0.0005 \\
(0.0001)\end{array}$ & $* * *$ & $\begin{array}{l}-0.0005 \\
(0.0001)\end{array}$ & $* * *$ & $\begin{array}{l}-0.0005 \\
(0.0001)\end{array}$ & $* * *$ & $\begin{array}{l}-0.0004 \\
(0.0001)\end{array}$ & $*$ & $\begin{array}{r}-0.0004 \\
(0.0001)\end{array}$ & $*$ & $\begin{array}{l}-0.0004 \\
(0.0001)\end{array}$ & $*$ & $\begin{array}{r}-0.0004 \\
(0.0001)\end{array}$ & $*$ \\
\hline Constant & $\begin{array}{r}-4.6103 \\
(0.7591)\end{array}$ & $* * *$ & $\begin{array}{r}-4.1989 \\
(0.7204)\end{array}$ & $* * *$ & $\begin{array}{r}-4.4036 \\
(0.7358)\end{array}$ & $* * *$ & $\begin{array}{r}-4.0063 \\
(0.7083)\end{array}$ & $* * *$ & $\begin{array}{r}-6.1502 \\
(0.8593)\end{array}$ & $* * *$ & $\begin{array}{r}-5.7351 \\
(0.8144)\end{array}$ & $* * *$ & $\begin{array}{r}-5.8157 \\
(0.8350)\end{array}$ & $* * *$ & $\begin{array}{r}-5.4914 \\
(0.8045)\end{array}$ & $* * *$ \\
\hline Pearson chi-squares & 285.11 & $* * *$ & 287.95 & $* * *$ & 286.18 & $* * *$ & 289.61 & $* * *$ & 365.40 & $* * *$ & 368.05 & $* * *$ & 368.60 & $* * *$ & 372.31 & $* * *$ \\
\hline
\end{tabular}


Table 3. Regression results for outcome-aspiration gap

\begin{tabular}{|c|c|c|c|c|c|c|c|c|}
\hline \multirow[b]{2}{*}{$\begin{array}{l}\text { Presidents' Council } \\
\text { membership }\end{array}$} & \multicolumn{2}{|c|}{ Model 1} & \multicolumn{2}{|c|}{ Model 2} & \multicolumn{2}{|c|}{ Model 3} & \multicolumn{2}{|c|}{ Model 4} \\
\hline & $\begin{array}{r}0.3853 \\
(0.1152)\end{array}$ & $* *$ & & & & & & \\
\hline Equity ties & & & $\begin{array}{r}0.0072 \\
(0.0032)\end{array}$ & + & & & & \\
\hline Debt ties & & & & & $\begin{array}{r}0.0097 \\
(0.0043)\end{array}$ & $*$ & & \\
\hline RoK definition & & & & & & & $\begin{array}{r}-0.1036 \\
(0.1031)\end{array}$ & \\
\hline Size & $\begin{array}{r}-1.1288 \\
(0.1634)\end{array}$ & $* * *$ & $\begin{array}{l}-1.0356 \\
(0.1545)\end{array}$ & $* * *$ & $\begin{array}{r}-1.0727 \\
(0.1563)\end{array}$ & $* * *$ & $\begin{array}{r}-0.9393 \\
(0.1452)\end{array}$ & $* * *$ \\
\hline Age & $\begin{array}{r}0.0050 \\
(0.0027)\end{array}$ & & $\begin{array}{r}0.0053 \\
(0.0027)\end{array}$ & & $\begin{array}{r}0.0053 \\
(0.0028)\end{array}$ & & $\begin{array}{r}0.0053 \\
(0.0028)\end{array}$ & \\
\hline Diversification & $\begin{array}{r}0.0475 \\
(0.1503)\end{array}$ & & $\begin{array}{r}0.0425 \\
(0.1512)\end{array}$ & & $\begin{array}{r}0.0530 \\
(0.1514)\end{array}$ & & $\begin{array}{r}0.0333 \\
(0.1516)\end{array}$ & \\
\hline Exports & $\begin{array}{r}0.0128 \\
(0.0032)\end{array}$ & $* * *$ & $\begin{array}{r}0.0126 \\
(0.0032)\end{array}$ & $* * *$ & $\begin{array}{r}0.0126 \\
(0.0032)\end{array}$ & $* * *$ & $\begin{array}{r}0.0117 \\
(0.0032)\end{array}$ & $* * *$ \\
\hline Current ratio & $\begin{array}{r}-0.0014 \\
(0.0008)\end{array}$ & & $\begin{array}{r}-0.0014 \\
(0.0008)\end{array}$ & & $\begin{array}{r}-0.0014 \\
(0.0008)\end{array}$ & & $\begin{array}{r}-0.0014 \\
(0.0008)\end{array}$ & \\
\hline Debt equity ratio & $\begin{array}{r}-0.0001 \\
(0.0001)\end{array}$ & & $\begin{array}{r}-0.0001 \\
(0.0001)\end{array}$ & & $\begin{array}{r}-0.0001 \\
(0.0001)\end{array}$ & & $\begin{array}{r}-0.0001 \\
(0.0001)\end{array}$ & \\
\hline Constant & $\begin{array}{r}5.8285 \\
(0.7642)\end{array}$ & $* * *$ & $\begin{array}{r}5.4020 \\
(0.7371)\end{array}$ & $* * *$ & $\begin{array}{r}5.5619 \\
(0.7388)\end{array}$ & $* * *$ & $\begin{array}{r}5.0581 \\
(0.6992)\end{array}$ & $* * *$ \\
\hline Pearson chi-squares & 836.22 & $* * *$ & 848.05 & $* * *$ & 842.15 & $* * *$ & 852.74 & $* * *$ \\
\hline
\end{tabular}


Table 4. Regression results for volatility

\begin{tabular}{|c|c|c|c|c|c|c|c|c|c|c|c|c|c|c|c|c|}
\hline \multirow[b]{3}{*}{$\begin{array}{l}\text { Presidents' Council } \\
\text { membership }\end{array}$} & \multicolumn{8}{|c|}{$\underline{\text { RoA }}$} & \multicolumn{8}{|c|}{$\underline{\operatorname{RoS}}$} \\
\hline & \multicolumn{2}{|c|}{ Model 1} & \multicolumn{2}{|c|}{ Model 2} & \multicolumn{2}{|c|}{ Model 3} & \multicolumn{2}{|c|}{ Model 4} & \multicolumn{2}{|c|}{ Model 5} & \multicolumn{2}{|c|}{ Model 6} & \multicolumn{2}{|c|}{ Model 7} & \multicolumn{2}{|c|}{ Model 8} \\
\hline & $\begin{array}{r}0.2480 \\
(0.1117)\end{array}$ & + & & & & & & & $\begin{array}{r}0.3153 \\
(0.0925)\end{array}$ & $* *$ & & & & & & \\
\hline Equity ties & & & $\begin{array}{r}0.0056 \\
(0.0032)\end{array}$ & & & & & & & & $\begin{array}{r}0.0060 \\
(0.0036)\end{array}$ & & & & & \\
\hline Debt ties & & & & & $\begin{array}{r}0.0073 \\
(0.0034)\end{array}$ & + & & & & & & & $\begin{array}{r}0.0092 \\
(0.0026)\end{array}$ & $* *$ & & \\
\hline RoK definition & & & & & & & $\begin{array}{r}-0.0086 \\
(0.0820)\end{array}$ & & & & & & & & $\begin{array}{r}-0.0705 \\
(0.0881)\end{array}$ & \\
\hline Size & $\begin{array}{r}-0.7810 \\
(0.1128)\end{array}$ & $* * *$ & $\begin{array}{r}-0.7347 \\
(0.1072)\end{array}$ & $* * *$ & $\begin{array}{r}-0.7569 \\
(0.1084)\end{array}$ & $* * *$ & $\begin{array}{c}-0.7161 \\
(0.1021)\end{array}$ & $* * *$ & $\begin{array}{r}-0.9750 \\
(0.1308)\end{array}$ & $* * *$ & $\begin{array}{r}-0.9072 \\
(0.1245)\end{array}$ & $* * *$ & $\begin{array}{r}-0.9466 \\
(0.1258)\end{array}$ & $* * *$ & $\begin{array}{r}-0.8385 \\
(0.1181)\end{array}$ & $* * *$ \\
\hline Age & $\begin{array}{r}0.0016 \\
(0.0021)\end{array}$ & & $\begin{array}{r}0.0021 \\
(0.0021)\end{array}$ & & $\begin{array}{r}0.0018 \\
(0.0021)\end{array}$ & & $\begin{array}{r}0.0022 \\
(0.0021)\end{array}$ & & $\begin{array}{r}0.0026 \\
(0.0023)\end{array}$ & & $\begin{array}{r}0.0031 \\
(0.0023)\end{array}$ & & $\begin{array}{r}0.0028 \\
(0.0023)\end{array}$ & & $\begin{array}{r}0.0031 \\
(0.0023)\end{array}$ & \\
\hline Diversification & $\begin{array}{r}0.0506 \\
(0.1175)\end{array}$ & & $\begin{array}{r}0.0553 \\
(0.1177)\end{array}$ & & $\begin{array}{r}0.0596 \\
(0.1175)\end{array}$ & & $\begin{array}{r}0.0630 \\
(0.1179)\end{array}$ & & $\begin{array}{r}-0.0405 \\
(0.1274)\end{array}$ & & $\begin{array}{c}-0.0408 \\
(0.1280)\end{array}$ & & $\begin{array}{r}-0.0296 \\
(0.1278)\end{array}$ & & $\begin{array}{r}-0.0381 \\
(0.1281)\end{array}$ & \\
\hline Exports & $\begin{array}{r}0.0131 \\
(0.0023)\end{array}$ & $* * *$ & $\begin{array}{r}0.0130 \\
(0.0023)\end{array}$ & $* * *$ & $\begin{array}{r}0.0130 \\
(0.0023)\end{array}$ & $* * *$ & $\begin{array}{r}0.0127 \\
(0.0023)\end{array}$ & $* * *$ & $\begin{array}{r}0.0120 \\
(0.0027)\end{array}$ & $* * *$ & $\begin{array}{r}0.0118 \\
(0.0027)\end{array}$ & $* * *$ & $\begin{array}{r}0.0119 \\
(0.0026)\end{array}$ & $* * *$ & $\begin{array}{r}0.0113 \\
(0.0026)\end{array}$ & $* * *$ \\
\hline Current ratio & $\begin{array}{r}-0.0002 \\
(0.0004)\end{array}$ & & $\begin{array}{r}-0.0003 \\
(0.0005)\end{array}$ & & $\begin{array}{r}-0.0002 \\
(0.0004)\end{array}$ & & $\begin{array}{r}-0.0003 \\
(0.0005)\end{array}$ & & $\begin{array}{r}-0.0004 \\
(0.0005)\end{array}$ & & $\begin{array}{r}-0.0005 \\
(0.0005)\end{array}$ & & $\begin{array}{r}-0.0004 \\
(0.0005)\end{array}$ & & $\begin{array}{r}-0.0005 \\
(0.0005)\end{array}$ & \\
\hline Debt equity ratio & $\begin{array}{r}-0.0001 \\
(0.0001)\end{array}$ & & $\begin{array}{r}-0.0001 \\
(0.0001)\end{array}$ & & $\begin{array}{r}-0.0001 \\
(0.0001)\end{array}$ & & $\begin{array}{r}0.0001 \\
(0.0001)\end{array}$ & & $\begin{array}{r}0.0001 \\
(0.0001)\end{array}$ & & $\begin{array}{r}0.0001 \\
(0.0001)\end{array}$ & & $\begin{array}{r}-0.0001 \\
(0.0001)\end{array}$ & & $\begin{array}{r}0.0001 \\
(0.0001)\end{array}$ & \\
\hline Constant & $\begin{array}{r}4.4275 \\
(0.5443)\end{array}$ & $* * *$ & $\begin{array}{r}4.1901 \\
(0.5196)\end{array}$ & $* * *$ & $\begin{array}{r}4.3028 \\
(0.5239)\end{array}$ & $* * *$ & $\begin{array}{r}3.9462 \\
(0.4951)\end{array}$ & $* * *$ & $\begin{array}{r}5.3878 \\
(0.6150)\end{array}$ & $* * *$ & $\begin{array}{r}5.0639 \\
(0.5919)\end{array}$ & $* * *$ & $\begin{array}{r}5.2418 \\
(0.5933)\end{array}$ & $* * *$ & $\begin{array}{r}4.8075 \\
(0.5657)\end{array}$ & $* * *$ \\
\hline Pearson chi-squares & 697.14 & $* * *$ & 702.09 & $* * *$ & 698.31 & $* * *$ & 709.08 & $* * *$ & 812.44 & $* * *$ & 822.53 & $* * *$ & 813.49 & $* * *$ & 828.11 & $* * *$ \\
\hline
\end{tabular}

